\title{
DEVELOPMENT SOCIAL ARITHMETIC MODULE USING PROBLEM SOLVING APPROACH ON SMP / MTS CLASS VII
}

\author{
Wahyu Melania ${ }^{a}$, Aris Thobirin ${ }^{b}$ \\ Program Studi Pendidikan Matematika FKIP UAD \\ Jalan Ring Road Selatan, Tamanan, Banguntapan, Bantul Yogyakarta \\ awhmelani@gmail.com, baris.thobi@math.uad.ac.id
}

\begin{abstract}
Teaching materials to help students understand the concept of social arithmetic and attract the attention of students is still lacking and does not motivate students in the learning process becomes a problem to do the research. Math module is one alternative teaching materials that can be used in the learning process. This research aims to develop a social arithmetic module using a problem solving approach students of class VII and assess the feasibility of the product being developed. The development of research in the Research and Development (R \& D). Subjects were expert assessment of the product, math teacher of MTs Class VII and students of class VII MTs. Subjects to be tested in this study were students of class VII of MTs Maguwoharjo Sleman. The research instrument used was a questionnaire and the type of data used is the quantitative and qualitative data. Data collection techniques used were interview, documentation and questionnaires. Data analysis techniques were used: (1) data analysis product assessment by subject matter experts and media experts, (2) data analysis product trials, analysis of trial data usage. The results of the research and development of social arithmetic module using a problem solving approach to the VII class of SMP / MTs. The results of the feasibility test of the material included in both criteria with an average score of 29.5 out of a maximum score of 40. For the feasibility study media included in both criteria with an average score of 30 out of a maximum score of 40 . While the results of the student questionnaire responses into the product trials both criteria with an average score of 39 out of a maximum score of 48 . The results of the questionnaire responses of students to test usage included in both criteria with an average score of 39.22 out of a maximum score of 48 . The results shown that social arithmetic material module using a problem solving approach to the claass VII in SMP / MTs eligible for use in the learning process.
\end{abstract}

Keywords: Module, Problem Solving, Social Arithmetic.

\section{INTRODUCTION}

Education is a process to improve the quality of human life. Education will influence the mindset, behavior, and development of one's personality. So that education is intended to form a person who is critical in thinking, responsible and increasing potential according to the individual's abilities. One of the educational processes is through formal and informal learning processes. Because in the learning process not only emphasizes the understanding of the material presented but in changes in personality, behavior and thinking in solving problems faced.

Mathematics is a science which in its learning and application requires thinking and reasoning in solving problems both social, economic and natural problems. Therefore school mathematics can function as a means to develop students' skills, knowledge and personality. Mathematics learning aims to enable students to understand mathematical concepts, convey mathematical ideas, solve mathematical problems, and apply them in daily life. However, sometimes the purpose of learning is sometimes not achieved due to several factors, one of which is the lack of teaching materials that support the learning itself.

Teaching materials can be an alternative in the learning process to facilitate students in understanding a mathematical concept. The presence of teaching materials can give students the 
opportunity to learn according to the abilities of each student. One teaching material that is easily developed is printed teaching materials in the form of modules.

Modules are teaching materials that contain learning activities from a chapter that is systematically arranged and used independently. Modules are useful so students are more independent and increase students' reading interest so that they are expected to be more interested in learning and improving their learning outcomes.

Besides that the learning process is said to be interesting when in the learning process students are able to feel challenged to learn the material and increase motivation to continue learning mathematics. Therefore, in preparing mathematics teaching materials in the form of modules it is expected to be able to challenge students in mathematics learning. Modules with a problem solving approach is one alternative that can challenge students in the learning process because the module uses problems as the main activities in learning. Problems given to students when learning with problem solving approaches can be problems that occur in everyday life, because often faced by each individual so students can understand well, or common problems faced by many people so that they can be utilized directly.

One of the learning materials that can be taught with modules is social arithmetic. In this material there are often questions in the form of story questions that look easy but sometimes students have difficulty understanding and translating questions. So teaching materials are needed that can help students understand the concept of social arithmetic.

Based on the results of interviews with class VII mathematics teachers on March 11, 2015 at MTs N Maguwoharjo Sleman, information was obtained that in the learning process mathematics teachers used teaching materials in the form of math package books, Student Activity Sheets (SAS) and mathematical modules. Teaching materials of mathematics subjects for class VII used are less attractive to students and do not motivate students in the process of learning mathematics.

In the process of learning mathematics in class VII of MTs N Maguwoharjo Sleman, teaching materials have not been used individually because of the limitations between the number of students and the number of teaching materials. Each student only has a Student Activity Sheet (SAS) and mathematics books for class VII are loaned to students when learning activities take place as learning resources and are returned when the math lesson is finished. Based on information from several students, students are more interested in learning to use teaching materials such as modules in which there are examples of material descriptions with colors that are not boring and media that can help learning independently or in groups, thus increasing students' interest in the learning process of mathematics.

Teaching materials used in the school have not used a problem solving approach. In the learning process teaching materials needed to function to improve thinking skills especially mathematical problem solving need to be developed teaching materials in the form of mathematical modules, thus encouraging the ability to solve mathematical problems that are important to help students understand concepts in mathematical learning and problem solving in life.

Other information obtained was that some students still find it difficult to understand social arithmetic material. Difficulties faced by students are in working on different problems with the examples given. Because students are less daring to ask when experiencing difficulties and only listen to explanations from the teacher, so that students' ability in problem solving is still lacking.

Based on the description above, researchers want to develop teaching materials in the form of mathematical modules using a problem solving approach in class VII for social arithmetic material. The module is expected to help students actively and independently, so that students can learn according to the speed and intensity of their learning.

\section{METHODS}

This research is research and development, which is a research method used to produce certain products, and test the effectiveness of these products (Sugiyono, 2012: 407). This development research 
is devoted to the development of teaching materials in the form of Social Arithmetic material modules with problem solving approaches. To be able to produce certain products used research that is needs analysis and to test the effectiveness of these products in order to function in the wider community, research is needed to test these products. The development procedure adopted in the R \& D (Sugiyono (2011: 409),) model is as follows:

1. Potential and problems

2. Data collection

3. Product design

4. Design validation

5. Revision of the design

6. Test the product

7. Product revision

8. Test usage

9. Product revision

10. Mass products

Complete development procedures can be described as follows:

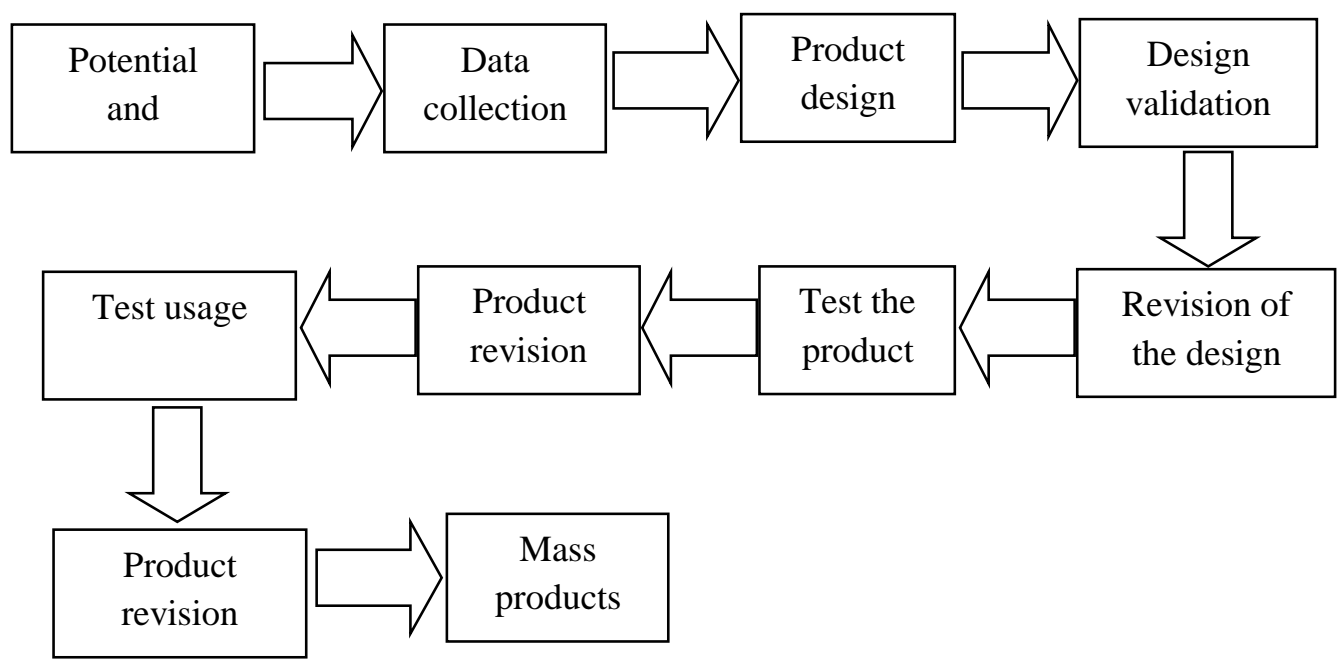

Picture 1. Steps for Developing a Research and Development Model (R \& D)

The technical analysis of the data used in this study uses qualitative and quantitative analysis techniques. Data obtained from questionnaires for material experts and media experts are converted into quantitative data. Then comments and suggestions provided by media experts and material experts be used to improve products developed before the trial process in the field. Whereas the results of the assessment obtained from product trial respondents and usage trials used a modified Likert scale from Sugiyono (2013: 135) and Sukarjo (2006: 52-53). After every aspect of learning media was assessed by students of MTs N Maguwoharjo Sleman, then the average score of each aspect was determined. Then it is transformed into the qualitative value of the learning media by using the ideal assessment category criteria. After the data is analyzed, it will be known the feasibility of learning media made.

\section{RESULT AND DISCUSSION}

\section{Potential and problems}

Before conducting the research, the researcher first conducted an interview with one of the mathematics subject teachers at MTs N Maguwoharjo Sleman. The interview was conducted with Ms. Dra. Daswati Sugeng Rahayu to gather information about problems and potential at school, obtained:

a. Teaching materials used have not used a problem solving approach. 
b. Some students still find it difficult to understand Social Arithmetic material.

c. Students' problem solving skills are still lacking.

d. The potential of students is that students will be interested in teaching materials coupled with attractive images and colors and media that can help learning independently or in groups.

\section{Data collection}

At the stage of collecting data, the researcher sought references and literature studies that supported the development of modules using a problem approach. Researchers obtain research references that are relevant to the research that will be conducted. In addition to reviewing relevant research, the researcher also analyzed SK-KD and asked the opinion of the mathematics teacher about the right material to be applied using a problem-solving approach.

The module on social arithmetic material uses a problem solving approach in class VII that meets basic Competency and Competency Standards.

\section{Product design}

In this stage the researcher performs the following steps, namely:

a. Determine competency standards, basic competencies, indicators and subject matter to be presented. The subjects taken by researchers in this development were 5 students for product testing and 32 students for trial use in class VII B at MTs N Maguwoharjo Sleman on Social Arithmetic material.

Competency standards : use the algebra form, equations and linear variables in one variable, and comparisons in problem solving.

Basic competencies $\quad: 3.3$ uses algebraic concepts in solving social arithmetic problems. Indicator:

1) Calculate the overall value, perunit value, and part value.

2) Determine the size and percentage of profit, loss, selling price, purchase price, rebate, and single interest in economic activity.

Subject matter :

1) Overall value, unit value and partial value

2) Price of purchase, sale, profit or loss

3) Rebates (discounts), gross, tara and net

4) Tax and savings interest (single interest)

b. Arranging learning media in the form of modules includes:

1) Front and back cover pages

2) The introduction section contains:
a) Preface
b) Table of contents
c) Instructions for using the module
d) Module parts
e) Concept Map
f) Standards of competence and basic competencies
g) Indicator

3) Section contents
a) Title of the chapter
b) Title of sub-chapter
c) Material
d) Activities
e) Sample questions
f) Exercise
g) Summary
h) Evaluation
i) Bibliography 


\section{Design validation}

In this design validation phase learning media developed were validated by material experts and media experts.

\section{Test the product}

This product trial was conducted at MTs N Maguwoharjo Sleman after the learning media was revised based on suggestions and input from experts and was declared feasible to test the product. The product trial was conducted on 5 students of class VII B at MTs N Maguwoharjo

\section{Product revision}

Product revisions are based on the analysis of product trial results at MTs N Maguwoharjo Sleman. MTS

\section{Test usage}

After making a revision based on the product trial, the researcher then conducted a trial using MTs Negeri Maguwoharjo Sleman, the respondents in the usage trial were 32 students of class VII B.

\section{Product revisions}

Product revisions are based on the analysis of data from the trial results of use at MTs N Maguwoharjo Sleman.

\section{Making mass products}

Based on the results of the trial trial usage and after revising the product, it can be concluded that the learning media developed can be used. Furthermore, the product will be made for the benefit of mathematics learning. But in this study, researchers did not carry out mass production.

\section{CONCLUSION}

The results of this study are teaching materials in the form of mathematical modules for class VII students of the subject matter of social arithmetic using problem solving approaches developed with the R \& D development model. The development steps presented by Sugiyono (2012: 409) include potential problems, data collection, product design, design validation, design revisions, product trials, product revisions, and usage trials.

The results of the feasibility test by material experts included in the good criteria with an average score of 29.5 from a maximum score of 40 . For the feasibility of expert learning media included in the criteria well with an average score of 30 from a maximum score of 40 . Whereas the results of the student response questionnaire to the test try the product into good criteria with an average score of 39 from a maximum score of 48 . And for the results of the questionnaire the response of students to the usage test is in good criteria with an average score of 39.22 from a maximum score of 48 .

Based on these assessments, it can be concluded that in general the teaching materials in the form of modules developed are included in the criteria of good. Teaching materials using modules with social arithmetic material problem solving in class VII is feasible to be used by teachers to teach in schools and students to study independently.

\section{REFERENCES}

Prastowo, Andi.2011.Panduan Kreatif Membuat Bahan Ajar Inovatif. Yogyakarta: DIVA Press.

Sugiyono. 2010. Metode Penelitian Pendidikan (Pendekatan Kuantitatif, Kualitatif, dan R\&D. Bandung: Alfabeta.

Suherman, Erman, dkk. 2003. Strategi Pembelajarn Matematika Kontemporer. Bandung: JICA. Sukarjo. 2006. Kumpulan Materi Evaluasi Pembelajaran. Yogyakarta: Pascasarjana UNY.

Rahmawati, Yunita .2009. Pengembangan Lembar Kegiatan Siswa Berbasis Pemecahan Masalah Pada Materi Bangun Ruang Sisi Datar untuk Siswa SMP Kelas VIII. Yogyakarta: Skripsi UAD. 